\title{
PELATIHAN PENYUSUNAN LAPORAN KEUANGAN PERUSAHAAN DAGANG SISWA SMA KATOLIK St. KRISTOFORUS
}

\author{
Agustin Ekadjaja ${ }^{1}$, Natasha Claudia Darmawan ${ }^{2}$, Amelya $^{3}$ \\ ${ }^{1}$ Jurusan Akuntansi , Universitas Tarumanagara, Jakarta \\ Surel :agustine@fe.untar.ac.id \\ 2 Jurusan Akuntansi , Universitas Tarumanagara, Jakarta \\ Surel: natasha.125180203@stu.untar.ac.id \\ ${ }^{3}$ Jurusan Akuntansi, Universitas Tarumanagara, Jakarta \\ Surel : amelya.125180574@stu.untar.ac.id
}

\begin{abstract}
This Community Service Activity (PKM) is one of the manifestations of the Tri Dharma of Higher Education, which is to provide benefits to the community. This PKM activity is intended for high school students of St.Kristoforus 1 Catholic School, which is located in the Grogol area, West Jakarta. The method of implementing this community service activity is done by providing online training. The target participants for this training are high school students of St.Kristoforus 1 Catholic School. For Universitas Tarumanagara, especially the Faculty of Economics and Business, it is a means to introduce Universitas Tarumanagara Colleges and is a community service activity carried out by Universitas Tarumanagara lecturers by involving active students of the Faculty of Economics and Business, Universitas Tarumanagara to be able to apply their knowledge to the community. This activity began with a meeting to explore the needs of the school in this collaboration. After receiving a good reception, we made a proposal for activities to the LPPM Universitas Tarumanagara. The topic chosen for this activity is preparing the financial statements of a trading company. This topic was chosen because of the importance of understanding in the preparation of financial statements to be able to measure the company's performance and financial position. The output produced from this community service activity is a module and as the last stage, we will make a report on the implementation of this Community Service (PKM) task and submit it as our responsibility to the LPPM Untar.
\end{abstract}

Keywords: Trading company, financial statements, accounting

\begin{abstract}
ABSTRAK
Kegiatan Pengabdian Kepada Masyarakat ini (PKM) merupakan salah satu perwujudan Tri Dharma Perguruan Tinggi, yaitu memberikan manfaat kepada masyarakat. Kegiatan PKM ini ditujukan bagi siswa - siswi SMA Katolik St.Kristoforus1 yang berlokasi di daerah Grogol, Jakarta Barat. Metode pelaksanaan kegiatan pengabdian masyarakat ini dilakukan dengan memberikan pelatihan secara daring. Target peserta pelatihan ini adalah siswa SMA Katolik St. Kristoforus 1. Bagi Universitas Tarumanagara-khususnya Fakultas Ekonomi dan Bisnis merupakan salah satu sarana untuk bisa memperkenalkan Perguruan Tinggi Universitas Tarumanagara dan merupakan kegiatan pengabdian kepada masyarakat yang dilakukan oleh Dosen Universitas Tarumanagara dengan melibatkan mahasiswa aktif Fakultas Ekonomi dan Bisnis Universitas Tarumanagara untuk dapat mengaplikasikan ilmu yang dimiliki kepada masyarakat. Kegiatan ini diawali dengan pertemuan untuk menggali kebutuhan pihak Sekolah dalam kerja sama ini. Setelah mendapat sambutan baik maka kami membuat proposal kegiatan kepada pihak LPPM Universitas Tarumangara. Topik yang dipilih untuk kegiatan ini adalah menyusun laporan keuangan perusahaan dagang. Topik ini dipilih karena mengingat pentingnya pemahaman dalam penyusunan laporan keuangan untuk dapat mengukur kinerja dan posisi keuangan perusahaan. Luaran yang dihasilkan dari kegiatan pengabdian masyarakat ini adalah modul dan sebagai tahap terakhir, kami akan membuat laporan pelaksanaan tugas Pengabdian Kepada Masyarakat (PKM) ini dan diserahkan sebagai pertanggung jawaban kami kepada pihak LPPM Untar.
\end{abstract}

Kata kunci: Perusahaan dagang, laporan keuangan, akuntansi

\section{PENDAHULUAN}

Perekonomian dunia saat ini sedang mengalami banyak perubahan karena dampak dari pandemi Covid 19. Perusahaan perlu sangat hati - hati dalam mengelola keuangan agar bisa tetap 
bertahan. Setiap perusahaan pada umumnya bertujuan mendapatkan keuntungan atau laba dalam menjalankan roda bisnisnya. Menurut Konchitchki \& Patatoukas (2014), laporan keuangan dapat digunakan untuk memprediksi perkembangan bisnis terkait dengan prediksi variabel makro dalam perekomian. Pemahaman manajemen dalam menyusun dan membaca laporan keuangan sangat penting untuk menentukan kebijakan dan pengambilan keputusan. Berdasarkan hasil penelitian Ahmed \& Safdar (2018), laporan keuangan mencerminkan kinerja suatu perusahaan pada waktu tertentu dan dapat digunakan untuk memprediksi harga saham perusahaan.

Osadchy, et al. (2018), pelaporan keuangan perusahaan merupakan suatu sistem integrasi data yang menginformasikan asset dan posisi keuangan perusahaan dari hasil kegiatan usahanya. Klasifikasi utama dari pencatatan laporan keuangan meliputi laporan posisi keuangan perusahaan, laporan rugi/laba, laporan perubahan modal, dan laporan arus kas memungkinkan pengguna informasi eksternal dan internal perusahaan mengidentifikasi kondisi perusahaan pada suatu perekonomian tertentu.

SMA St Kristoforus 1, merupakan salah satu sekolah swasta yang cukup terkenal di Jakarta, yang berlokasi di Jalan Rahayu No 1 A, Jelambar, Grogol, Jakarta Barat (Gambar 1). SMA St. Kristoforus 1 bertekad untuk membimbing anak didiknya menjadi cerdas, bermartabat, siap bekerja dan dapat menjadi wirausahawan sukses. Salah satu ketrampilan yang dibutuhkan untuk menjadi wirausahawan sukses adalah kemampuan untuk menyusun penerimaan dan pengeluaran dana perusahaan yang tercermin pada laporan keuangan perusahaan.

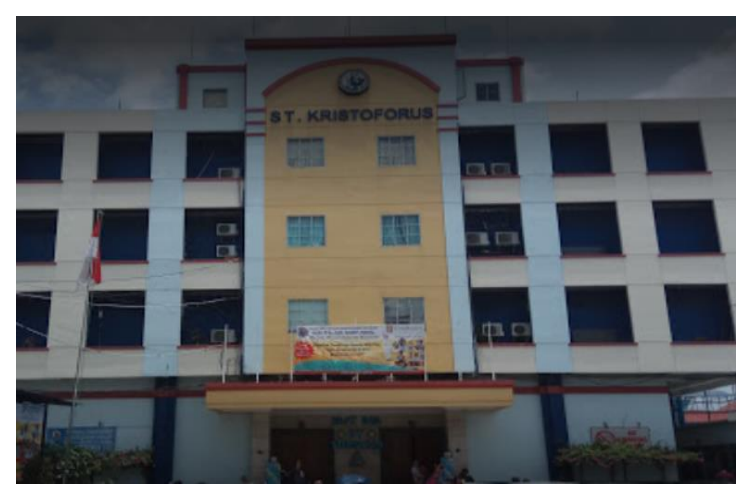

\section{Gambar 1 Gedung sekolah St Kristoforus 1}

Gambar 1 menunjukkan tempat kegiatan belajar mengajar di St Kristoforus 1 dengan jenjang pendidikan KB, TK, SD, SMP, dan SMA. Pada jenjang pendidikan SMA terbagi menjadi dua penjuruan, yaitu IPA dan IPS.

Dalam penjuruan IPS terdapat matapelajaran akuntansi. Namun, pihak SMA St Kritoforus menyadari bahwa ilmu akuntansi sangatlah luas dan kompleks, sementara tenaga pengajarnya masih terbatas. SMA St. Kristoforus 1 menyambut baik tim abdimas FEB UNTAR jurusan Akuntansi untuk memberikan pelatihan terkait dengan laporan keuangan perusahaan dagang yang dapat meningkatkan pengetahuan dan ketrampilan anak didiknya dalam bidang akuntansi tidak hanya terkait dengan teori saja namun juga dalam hal praktek.

Hal tersebut dikarenakan Akuntansi merupakan suatu seni mengenai pencatatan dan pengelompokan dalam pelaporan hasil suatu kegiatan bisnis. Hasil dari pelaporan merupakan dasar bagi pimpinan dalam pengambilan keputusan bisnis. Menurut Hery (2018), "Laporan keuangan adalah hasil akhir dari pencatatan yang merupakan suatu ringkasan dari transaksi576 


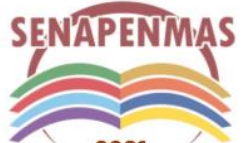

2021
Seminar Nasional Hasil Penelitian dan Pengabdian Kepada Masyarakat 2021

Pengembangan Ekonomi Bangsa Melalui Inovasi Digital Hasil Penelitian dan Pengabdian Kepada Masyarakat Jakarta, 21 Oktober 2021

transaksi keuangan yang terjadi selama tahun buku yang bersangkutan. Dengan kata lain, laporan keuangan ini berfungsi sebagai alat informasi yang menghubungkan perusahaan dengan pihakpihak yang berkepentingan, yang menunjukkan kondisi kesehatan perusahaan dan kinerja perusahaan".

Berdasarkan hasil diskusi dengan pihak sekolah, tim abdimas merumuskan permasalahan mitra sebagai berikut :

1. Bagaimana cara menyusun dan menganalisa laporan keuangan terkait dengan kegiatan bisnis saat ini ?

2. Apakah laporan keuangan tersebut sesuai dengan Standar Akuntansi Keuangan yang terbaru?

\section{Solusi Permasalahan}

Sekolah SMA Katolik St. Kristoforus mempunyai misi untuk mempersiapkan anak didiknya yang merupakan memiliki bekal sebagai wirausahawan sukses yang mampu membuat dan memahami laporan keuangan bagi perusahaan dagang. Namun pihak Sekolah SMA Katolik St. Kristoforus menyadari masih terbatasnya pengetahuan yang harus dipersiapkan dalam pemahaman dan penyusunan laporan keuangan perusahaan dagang.

Solusi Permasalahan dari kegiatan PKM ini adalah adanya kebutuhan informasi dari Sekolah Katolik St. Kristoforus untuk menambah wawasan anak didik terhadap pemahaman dan penyusunan laporan keuangan perusahaan dagang. Namun terdapat kendala keterbatasan sumber daya yang ada dalam pengetahuan dan materi, sehingga diperlukan wawasan dari luar mengenai pengembangan laporan keuangan perusahaan dagang.

Tim PKM UNTAR bekerjasama dengan Sekolah Katolik St. Kristoforus untuk menambah wawasan anak didik Sekolah Katolik St. Kristoforus terhadap pemahaman laporan keuangan perusahaan dagang. Diharapkan Tim PKM Universitas Tarumanagara dapat membantu memberikan informasi terkini materi dan wawasan dalam meningkatkan wawasan anak didik Sekolah Katolik St. Kristoforus dengan memberikan pelatihan secara daring. Pelatihan yang diberikan berupa pemaparan materi penyusunan laporan keuangan perusahaan dagang.

Pelatihan dalam bentuk webinar dilakukan karena kondisi yang sedang tidak memungkinkan untuk mengadakan pelatihan secara tatap muka sehubungan dengan adanya pandemi Covid 19 yang sedang terjadi, sehingga terdapat pembatasan untuk jumlah peserta pertemuan dalam satu ruangan.

Materi yang akan diberikan kepada siswa SMA Katolik St. Kristoforus mengadopsi dari Standar Akuntansi Keuangan (SAK ) yang dikeluarkan oleh Ikatan Akuntan Indonesia yang mengacu kepada International Financial Reporting Standard (IFRS).

Melalui Webinar yang akan dilaksanakan oleh Tim PKM Universitas Tarumanagara pengetahuan siswa/siswi Sekolah Katolik St. Kristoforus tetap dapat ditingkatkan terutama wawasan mengenai pentingnya pemahaman dan Analisa laporan keuangan bagi perusahaan dagang.

\section{METODE PELAKSANAAN PKM}

Sehubungan dengan kondisi Pandemi Covid - 19 yang sedang terjadi, dan adanya pemberlakukan PPKM ( Perberlakukan Pembatasan Kegiatan Masyarakat) yang ditetapkan oleh pemerintah diberlakukan untuk mencegah meningkatnya penyebaran dan kenaikan angka penularan Covid - 19, maka kegiatan Pengabdian Masyarakat ini dikemas dalam bentuk webinar, diskusi dan pemecahan masalah mengenai pemahaman laporan keuangan bagi perusahaan dagang. 
Metode pelaksanaan kegiatan pengabdian masyarakat dalam pelaksaan Webinar bagi siswa SMA Katolik St. Kristoforus 1 adalah sebagai berikut:

\section{Pertemuan awal}

Pada pertemuan awal, tim PKM akan melakukan investigasi mengenai tujuan dari khalayak mitra untuk meningkatkan pengetahuan siswa didik dalam SMA Katolik St. Kristoforus mengenai pengetahuan pelaporan keuangan perusahaan dagang.

\section{Diskusi mengenai analisis materi webinar}

Setelah mengetahui kebutuhan akan peningkatan materi webinar pada siswa didik SMA Katolik St. Kristoforus, maka disiapkan rencana untuk melaksanakan kegiatan Webinar bagi siswa SMA Katolik St. Kristoforus.

\section{Diskusi mengenai perencanaan pelaksanaan Webinar}

Persiapan untuk pelaksanaan kegiatan Webinar bagi siswa SMA Katolik St. Kristoforus yang karena pandemi Covid untuk saat ini maka pelaksanaan kegiatan dilakukan secara daring dengan media zoom.

\section{Evaluasi perencanaan Webinar}

Merupakan tahap terakhir dari perencanaan kegiatan Webinar bagi siswa sekolah SMA Katolik St. Kristoforus.

Kegiatan Pengabdian Masyarakat dilakukan pada bulan September - November 2021 dengan durasi waktu pelaksanaan sekitar dua jam secara daring dengan menggunakan platform zoom. Pembicara dalam kegatan ini adalah Agustin Ekadjaja, SE., M.Si.,Ak.,CA.,dengan dibantu oleh 2 mahasiswa FEB Universitas Tarumanagara Natasha Claudia Darmawan dan Amelya. Evaluasi dilakukan di akhir kegiatan dengan menyebarkan form evaluasi mengenai manfaat kegiatan ini. Dan hasil evaluasi menyatakan bahwa kegiatan memberikan manfaat dalam meningkatkan pengetahuan dan pemahaman dalam penyusunan laporan keuangan perusahaan dagang bagi siswa - siswi SMA St. Kristoforus 1.

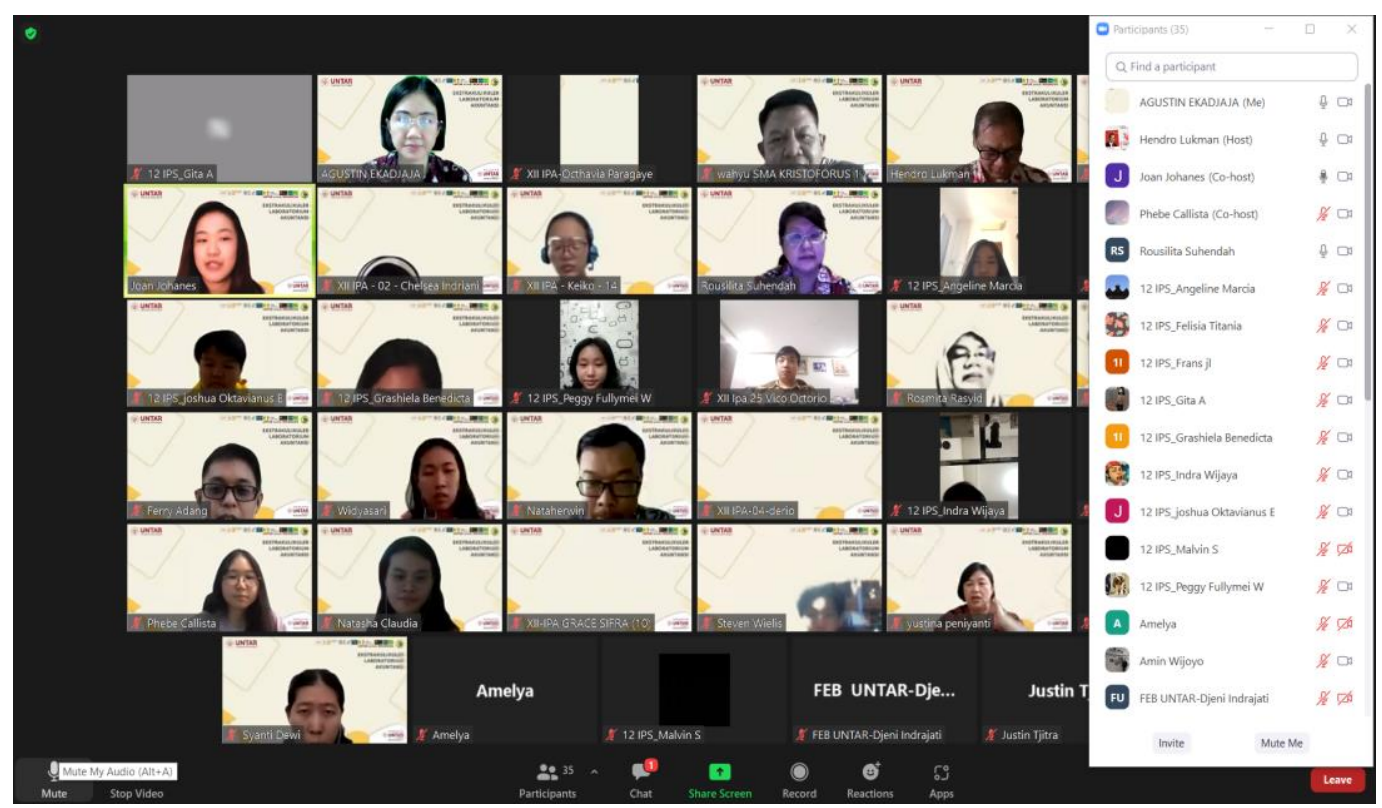

Gambar 2 Tim abidmas Untar bersama guru dan siswa SMA Katolik St. Kristoforus 1 


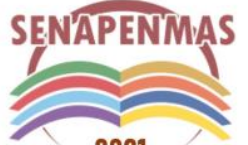

2021
Seminar Nasional Hasil Penelitian dan Pengabdian Kepada Masyarakat 2021

Pengembangan Ekonomi Bangsa Melalui Inovasi Digital Hasil Penelitian dan Pengabdian Kepada Masyarakat Jakarta, 21 Oktober 2021

\section{HASIL DAN PEMBAHASAN}

Sekolah SMA Katolik St. Kristoforus mempunyai misi untuk mempersiapkan anak didiknya memiliki bekal sebagai wirausahawan sukses yang mampu membuat dan memahami laporan keuangan bagi perusahaan dagang. Namun pihak Sekolah SMA Katolik St. Kristoforus 1 menyadari masih terbatasnya pengetahuan yang harus dipersiapkan dalam pemahaman dan penyusunan laporan keuangan perusahaan dagang.

Solusi Permasalahan dari kegiatan PKM ini adalah adanya kebutuhan informasi dari Sekolah Katolik St. Kristoforus 1 untuk menambah wawasan anak didik terhadap pemahaman dan penyusunan laporan keuangan perusahaan dagang. Namun terdapat kendala keterbatasan sumber daya yang ada dalam pengetahuan dan materi, sehingga diperlukan wawasan dari luar mengenai pengembangan laporan keuangan perusahaan dagang.

Tim PKM UNTAR bekerjasama dengan Sekolah Katolik St. Kristoforus 1 untuk menambah wawasan anak didik Sekolah Katolik St. Kristoforus 1 terhadap pemahaman laporan keuangan perusahaan dagang. Diharapkan Tim PKM Universitas Tarumanagara dapat membantu memberikan informasi terkini materi dan wawasan dalam meningkatkan wawasan anak didik Sekolah Katolik St. Kristoforus 1 dengan memberikan pelatihan secara daring. Pelatihan yang diberikan berupa pemaparan materi penyusunan laporan keuangan perusahaan dagang.

Materi yang akan diberikan kepada siswa SMA Katolik St. Kristoforus 1 mengadopsi dari Standar Akuntansi Keuangan (SAK) yang dikeluarkan oleh Ikatan Akuntan Indonesia yang mengacu kepada International Financial Reporting Standard (IFRS).

Melalui Webinar yang akan dilaksanakan oleh Tim PKM Universitas Tarumanagara pengetahuan siswa/siswi Sekolah Katolik St. Kristoforus tetap dapat ditingkatkan terutama wawasan mengenai pentingnya pemahaman dan Analisa laporan keuangan bagi perusahaan dagang. Dengan memahami Analisa dan pembuatan laporan keuangan perusahaan dagang, siswa/siswi Sekolah Katolik St. Kristoforus tidak hanya mendapatkan pengetahuan, tetapi juga memungkinkan untuk bisa diterapkan langsung jika siswa/siswi Sekolah Katolik St. Kristoforus melakukan kegiatan penjualan secara online sehingga dapat menambah penghasilan selama masa pandemi COVID - 19.

Bentuk-Bentuk Laporan Keuangan Laporan

\section{Laporan Laba Rugi}

Laporan Laba Rugi menyajikan saldo Pendapatan yang akan dikurangkan dengan Beban beban yang terjadi selama satu periode pelaporan. Laporan laba rugi akan memberikan informasi kinerja perusahaan selama satu periode. Dalam penyajian laporan laba rugi perusahaan dagang, pendapatan diperoleh dari penjualan setelah dikurangkan dengan retur penjualan dan potongan penjualan. Beban yang terjadi dari perusahaan dagang meliputi beban produksi dan beban yang terjadi selama periode pelaporan.

\section{Laporan Perubahan Laba}

Laporan Perubahan Laba menyajikan saldo Retained Earning (laba ditahan) akhir yang didapat dengan menghitung saldo laba ditahan awal ditambah laba bersih atau dikurangi rugi bersih dan dikurangkan juga dengan dividen pada tahun berjalan jika pada periode pelaporan perusahaan membagikan deviden.

\section{Laporan Perubahan Posisi Keuangan}

Laporan Perubahan Posisi Keuangan (Statement of Financial Statement) dahulu disebut Laporan Keuangan ( Financial Statement / Neraca). Laporan ini berisi asset, kewajiban dan ekuitas perusahaan, dimana saldo Laba Ditahan diperoleh dari Laporan Perubahan Laba. 
Kegiatan Pengabdian Masyarakat ini dilakukan oleh dosen yang mempunyai kompetensi dalam bidang penyusunan dan pelaporan laporan keuangan bagi perusahaan dagang dan telah membimbing mahasiswa dalam pengajaran penyusuan laporan keuangan. Manfaat bagi mahasiswa yang terlibat dalam kegiatan PKM adalah dapat lebih memahami dan pengalaman kegiatan dan belajar di luar kampus sesuai dengan Merdeka Belajar Kampus Merdeka (MBKM) menjadikan kegiatan ini merupakan menambah wawasan dan pengembangan soft-skill.

Target capaian kegiatan ini adalah memberikan wawasan mengenai penyusunan dan Analisa laporan keuangan perusahaan dagang. Luaran yang akan dihasilkan berupa Modul untuk kepentingan siswa atau sekolah SMA Katolik St. Kristoforus 1 dan juga publikasi dalam Senapenmas Untar. Materi pelatihan dituangkan dalam bentuk modul dengan tujuan modul tersebut dapat dijadikan sebagai pedoman dalam pelaksanaan kegiatan PKM sesuai dengan tujuan yang ingin dicapai.

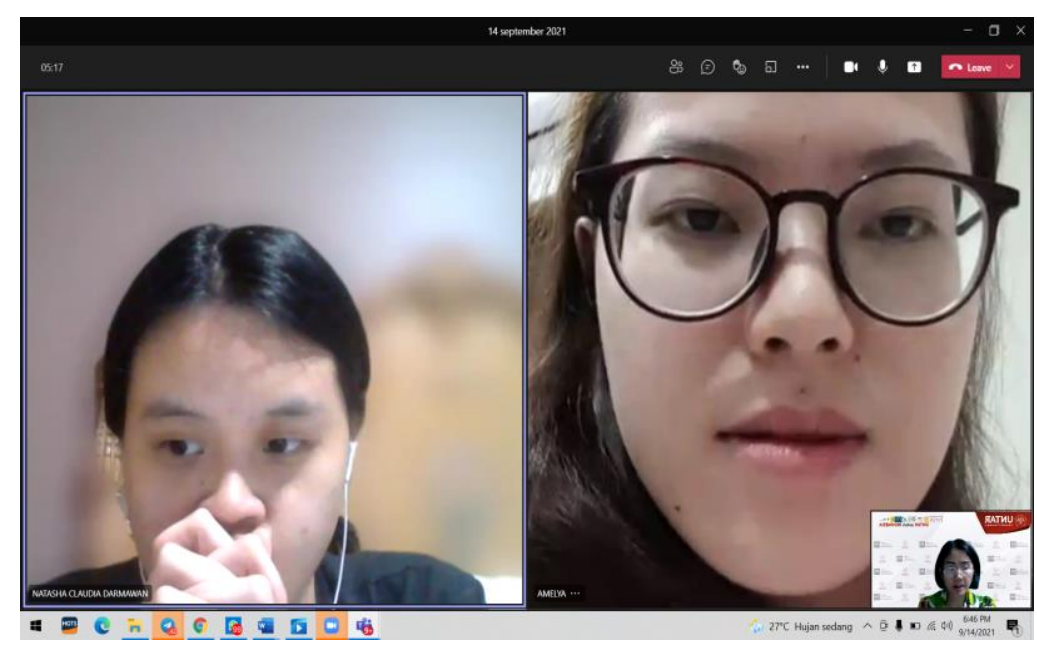

Gambar 3 Rapat kegiatan PKM dengan mahasiswa FEB UNTAR

Rapat kegiatan PKM (terlihat pada gambar 3) dilakukan oleh Tim PKM UNTAR sebelum pelaksanaan kegiatan PKM guna kelancaran dalam kegiatan PKM. Pada rapat selain membahas mengenai persiapan materi pelatihan juga dibahas mengenai job description masing-masing anggota tim.

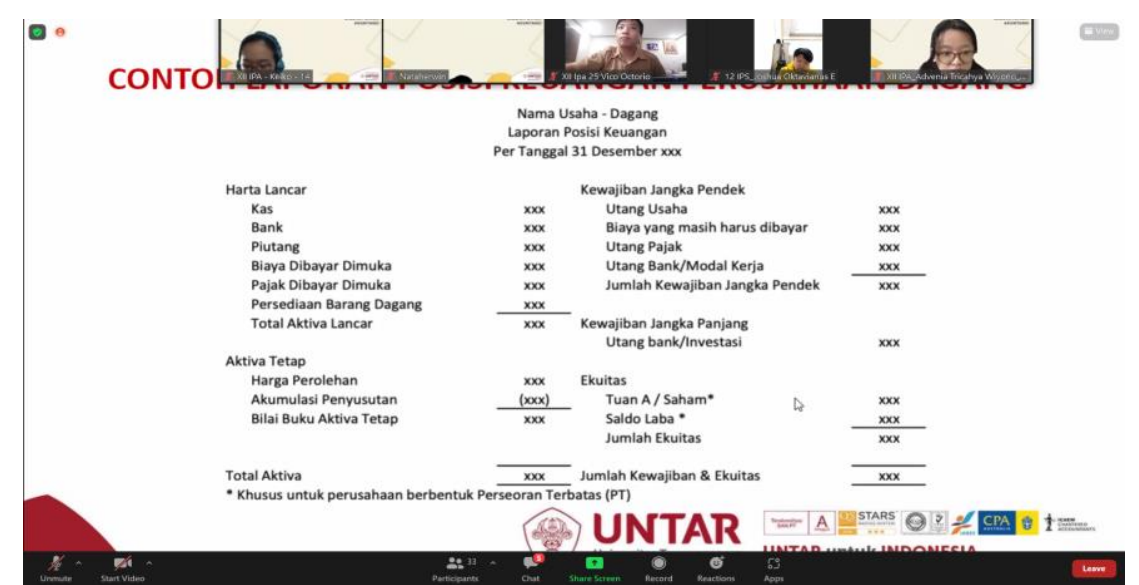

Gambar 4 Pemaparan materi pada pelaksanaan kegiatan PKM 


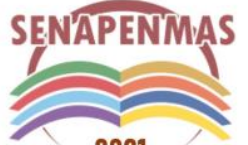

2021
Seminar Nasional Hasil Penelitian dan Pengabdian Kepada Masyarakat 2021

Pengembangan Ekonomi Bangsa Melalui Inovasi Digital Hasil Penelitian dan Pengabdian Kepada Masyarakat Jakarta, 21 Oktober 2021

Gambar 4 menunjukkan pelaksanaan pelatihan secara daring yang dilakukan oleh Tim PKM UNTAR dengan SMA Katolik St. Kristoforus 1 dengan topik Penyusunan Laporan Keuangan Perusahaan Dagang.

Tabel 1. Hasil Evaluasi Peserta Pelatihan

\begin{tabular}{lccc}
\hline Pertanyaan & Paham & Cukup Paham & Tidak Paham \\
\hline Saya memahami laporan laba rugi & 8 & 14 & 0 \\
\hline Saya memahami laporan perubahan modal & 10 & 12 & 0 \\
\hline Saya memahami laporan posisi keuangan & 6 & 16 & 0 \\
\hline $\begin{array}{l}\text { Saya memahami analisa laporan keuangan } \\
\text { secara keseluruhan }\end{array}$ & 6 & 16 & 0 \\
\hline Sumberan
\end{tabular}

Sumber : Hasil Data Penulis (2021)

Pada akhir sesi pelatihan, siswa-siswi SMA Katolik St Kristoforus diberikan kuesioner melalui google form dimana hasil kuesioner tersebut digunakan tim PKM untuk mengevaluasi hasil dari kegiatan PKM. Hasil kegiatan PKM tertera pada Tabel 1 dan dapat disimpulkan peserta pelatihan memahami materi yang dipaparkan dengan baik dalam hal laporan laba rugi, laporan perubahan modal, laporan posisi keuangan dan analisa laporan keuangan secara keseluruhan.

\section{KESIMPULAN}

Mitra pada kegiatan PKM adalah sekolah SMA Katolik St Kristoforus 1 yang mempunyai misi mempersiapkan anak didiknya menjadi wirausahawan sukses. Salah satu ketrampilan yang harus dimiliki oleh seorang wirausahawan sukses adalah kemampuan untuk menyusun laporan keuangan perusahaan. Namun, pihak SMA St Kritoforus menyadari bahwa ilmu akuntansi sangatlah luas dan kompleks, sementara tenaga pengajarnya masih terbatas. SMA Katolik St Kristoforus meminta kesediaan Tim PKM FEB UNTAR jurusan akuntansi untuk memberikan pelatihan mengenai penyusunan laporan keuangan perusahaan dagang.

Kegiatan PKM Universitas Tarumanagara telah berjalan dengan baik dan mendapat dukungan dari mitra SMA Katolik St. Kristoforus 1 untuk pelaksanaan Webinar bagi siswa - siswi dan para guru SMA Katolik St. Kristoforus 1.

Pelatihan diberikan dalam bentuk webinar karena kondisi yang sedang tidak memungkinkan untuk mengadakan pelatihan secara tatap muka sehubungan dengan adanya pandemi Covid 19 yang sedang terjadi, sehingga terdapat pembatasan untuk jumlah peserta pertemuan dalam satu ruangan.

Besar harapan mitra, setelah kegiatan webinar, pengetahuan siswa - siswi dan guru - guru akan lebih meningkat, terutama pengetahuan mengenai laporan keuangan perusahaan dagang yang dapat menjadi bekal bagi peserta webinar. Pihak mitra SMA Katolik St. Kristoforus 1 juga mengharapkan agar kegiatan dilaksanakan secara berkesinambungan karena merasakan manfaat yang besar untuk mempersiapkan siswa ke jenjang perguran tinggi.

\section{UCAPAN TERIMA KASIH (Acknowledgement)}

Kami mengucapkan terima kasih kepada semua pihak yang telah mendukung terlaksananya kegiatan pelatihan yang kami lakukan, yaitu: Rektor Universitas Tarumanagara, Ketua Lembaga Penelitian dan Pengabdian Kepada Masyarakat Universitas Tarumanagara, Dekan dan segenap pimpinan Fakultas Ekonomi dan Bisnis Universitas Tarumanagara, SMA Katolik St.Kristoforus 1 , serta semua pihak yang tidak dapat kami sebutkan satu per satu. 


\section{REFERENSI}

Ahmed, A. S., \& Safdar, I. (2018). Dissecting stock price momentum using financial statement analysis. Accounting and finance, 58, 3-43.https://doi.org/10.1111/acfi.12358.

Konchitchki, Y., \& Patatoukas, P. N. (2014). Taking the pulse of the real economy using financial statement analysis: Implications for macro forecasting and stock valuation. Accounting review, 89(2), 669-694https://doi.org/10.2308/accr-50632.

Osadchy, E. A., Akhmetshin, E. M., Amirova, E. F., Bochkareva, T. N., Gazizyanova, Y. Y., \& Yumashev, A. V. (2018). Financial statements of a company as an information base for decision-making in a transforming economy. European research studies journal, 21(2), 339-350.https://doi.org/10.35808/ersj/1006.

Hery. (2018). Analisis laporan keuangan: integrated and comprehensive. Cetakan ketiga. Jakarta : PT Gramedia.

Ikatan Akuntan Indonesia. (2019). Standar Akuntansi Keuangan ( SAK) Efektif per 1 Januari 2019. Jakarta: IAI.

Kartomo \& Sudarman,L.(2019).Buku Ajar Dasar-Dasar Akuntansi.Yogyakarta : Deepublish.

Kieso, Donald; Jerry J Weygandt, Terry D Warfield (2017). Intermediate Accounting: IFRS Edition, 3rd edition. United States of America : Wiley.

Wahyudiono, Bambang. (2014). Mudah membaca laporan keuangan. Jakarta:Raih asa sukses

Weygandt, J.J, Kimmel, P.D, and Kieso, D.E. (2019). Financial Accounting: IFRS Edition. Third Edition. United States of America: John Willey \& Sons, Inc.

Yuniarwati, Linda Santioso, Agustin Ekadjaja, Nurainun Bangun. (2021). Pengantar akuntansi : belajar mudah akuntansi. Edisi kedua. Jakarta : Mitra Wacana Media. 